\title{
OPEN Author Correction: 3D Printed Polyvinyl Alcohol Tablets with Multiple Release Profiles
}

\section{Xiaowen Xu, Jingzhou Zhao, Maonan Wang, Liang Wang \& Junliang Yang}

Correction to: Scientific Reports https://doi.org/10.1038/s41598-019-48921-8, published online 28 August 2019

This Article contains errors in References 1, 20, 45, 56 and 57 which were incorrectly given as:

Xiong, Y. J. et al. Structural broadband absorbing metamaterial based on three-dimensional printing technology. Acta Phys. Sin. 67, 084202, https://doi.org/10.1007/s12110-009-9068-2 (2018).

Liang, K., Carmone, S., Brambilla, D. \& Leroux, J. C. 3D printing of a wearable personalized oral delivery device: A first-in-human study. Sci Adv 4, eaat2544, https://doi.org/ARTN eaat254410.1126/sciadv.aat2544 (2018).

Chai, X. Y. et al. Fused Deposition Modeling (FDM) 3D Printed Tablets for Intragastric Floating Delivery of Domperidone. Sci. Rep. 7, 2829, https://doi.org/ARTN 282910.1038/ s41598-017-03097-x (2017).

He, S. et al. Low-temperature-cured highly conductive composite of Ag nanowires \& polyvinyl alcohol. Chin. Phys. B 26, 078103, https://doi.org/Artn07810310.1088/1674-1056/26/7/078103 (2017).

Liang, Z. et al. Facile Synthesis of Nitrogen-Doped Microporous Carbon Spheres for High Performance Symmetric Supercapacitors. Nanoscale Res. Lett. 13, 314-314 (2018).

The correct References are listed below as references $1-5$ respectively.

\section{References}

1. Xiong, Y. J. et al. Structural broadband absorbing metamaterial based on three-dimensional printing technology. Acta Phys. Sin 67, 084202, https://doi.org/10.7498/aps.67.20172262 (2018).

2. Liang, K., Carmone, S., Brambilla, D. \& Leroux, J. C. 3D printing of a wearable personalized oral delivery device: A first-in-human study. Sci. Adv. 4, eaat2544, https://doi.org/10.1126/sciadv.aat2544 (2018).

3. Chai, X. Y. et al. Fused Deposition Modeling (FDM) 3D Printed Tablets for Intragastric Floating Delivery of Domperidone. Sci. Rep. 7, 2829, https://doi.org/10.1038/s41598-017-03097-x (2017).

4. He, S. et al. Low-temperature-cured highly conductive composite of Ag nanowires \& polyvinyl alcohol. Chin. Phys. B 26, 078103, https://doi.org/10.1088/1674-1056/26/7/078103 (2017).

5. Liang, Z. et al. Facile Synthesis of Nitrogen-Doped Microporous Carbon Spheres for High Performance Symmetric Supercapacitors. Nanoscale Res. Lett. 13, 314, https://doi.org/10.1186/s11671-018-2713-0 (2018).

(c) (i) Open Access This article is licensed under a Creative Commons Attribution 4.0 International License, which permits use, sharing, adaptation, distribution and reproduction in any medium or format, as long as you give appropriate credit to the original author(s) and the source, provide a link to the Creative Commons license, and indicate if changes were made. The images or other third party material in this article are included in the article's Creative Commons license, unless indicated otherwise in a credit line to the material. If material is not included in the article's Creative Commons license and your intended use is not permitted by statutory regulation or exceeds the permitted use, you will need to obtain permission directly from the copyright holder. To view a copy of this license, visit http://creativecommons.org/licenses/by/4.0/.

(C) The Author(s) 2020 